\title{
Impact of nitrogen and climate change interactions on ambient air pollution and human health
}

\author{
Jennifer L. Peel • Richard Haeuber • \\ Valerie Garcia • Armistead G. Russell • \\ Lucas Neas
}

Received: 16 July 2012 / Accepted: 1 August 2012/Published online: 2 September 2012

(C) The Author(s) 2012. This article is published with open access at Springerlink.com

\begin{abstract}
Nitrogen oxides $\left(\mathrm{NO}_{\mathrm{x}}\right)$ are important components of ambient and indoor air pollution and are emitted from a range of combustion sources, including on-road mobile sources, electric power generators, and non-road mobile sources. While anthropogenic sources dominate, $\mathrm{NO}_{\mathrm{x}}$ is also formed by lightning strikes and wildland fires and is also emitted by soil. Reduced nitrogen (e.g., ammonia, $\mathrm{NH}_{3}$ ) is also emitted by various sources, including fertilizer application and animal waste decomposition. Nitrogen oxides, ozone $\left(\mathrm{O}_{3}\right)$ and fine particulate matter $\left(\mathrm{PM}_{2.5}\right)$ pollution related to atmospheric emissions of nitrogen $(\mathrm{N})$ and other pollutants can cause premature death and a variety of serious health effects. Climate change is expected to impact how N-related pollutants affect human health. For example, changes in temperature and precipitation patterns are projected to both lengthen the $\mathrm{O}_{3}$ season and intensify high $\mathrm{O}_{3}$ episodes in some areas. Other climate-related changes may
\end{abstract}

\footnotetext{
J. L. Peel ( ()

Department of Environmental and Radiological Health

Services, Colorado State University, Fort Collins,

CO 80523, USA

e-mail: Jennifer.Peel@colostate.edu

R. Haeuber · V. Garcia · L. Neas

U.S. Environmental Protection Agency,

Washington, DC, USA

A. G. Russell

Environmental Engineering, Georgia Institute

of Technology, Atlanta, GA 30332, USA
}

increase the atmospheric release of $\mathrm{N}$ compounds through impacts on wildfire regimes, soil emissions, and biogenic emissions from terrestrial ecosystems. This paper examines the potential human health implications of climate change and $\mathrm{N}$ cycle interactions related to ambient air pollution.

Keywords Nitrogen oxides - Ozone - Air pollution · Human health

\section{Introduction}

Reactive nitrogen $(\mathrm{Nr})$, including both anthropogenic and natural nitrogen $(\mathrm{N})$ emissions, plays an important role in ambient air quality and subsequent impacts on human health. Here we describe the interactions of $\mathrm{Nr}$ and global climate change on ambient air quality and subsequent human health impacts, as displayed in Fig. 1. We describe the role of $\mathrm{Nr}$ in ambient air pollution formation, including nitrogen oxides $\left(\mathrm{NO}_{\mathrm{x}}\right)$, ozone $\left(\mathrm{O}_{3}\right)$, and particulate matter (PM). We summarize the evidence regarding the human health effects of these ambient pollutants. Finally, we discuss implications of nitrogen and climate change interaction on policy and provide recommendations and key research needs.

Global climate change is predicted to have adverse consequences to human health through many pathways outside of the those described within this paper; these additional pathways have been previously described (see Confalonieri et al. 2007; Haines and 
Fig. 1 Interactions of factors likely to change due to global climate change (red) and $\mathrm{Nr}$ in the environment (green), and their impact on ambient air pollution concentrations, human exposure, and subsequent human health effects (blue). Health effects will be influenced by susceptibility and vulnerability factors (purple). Note that the term "temperature" is used for simplicity; this factor will likely act through extreme temperature events (heat waves) and/or stagnation events rather than mean temperature

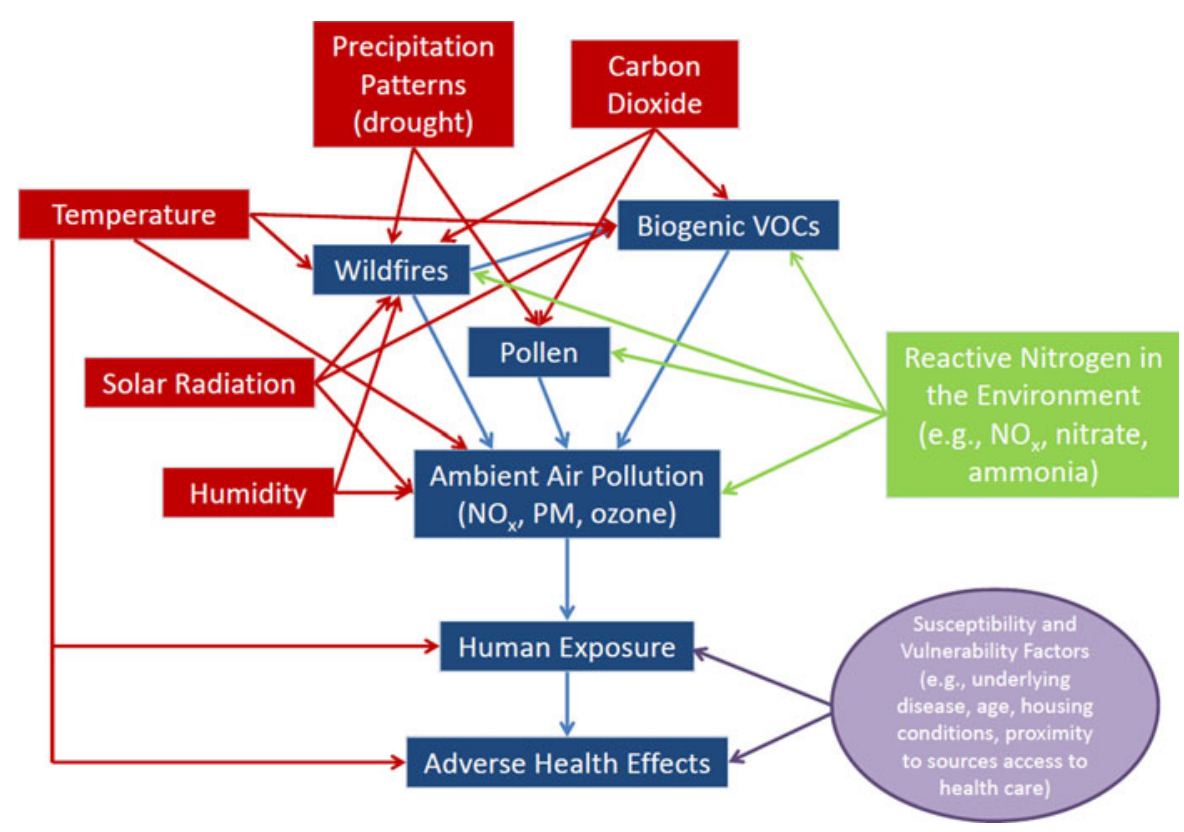

Patz 2004; Houghton et al. 2001; Institute of Medicine (IOM) 2011). Examples of these predicted adverse health consequences include the following: increased illnesses and deaths due to an increased frequency of heat waves, particularly in traditionally cooler climates; physical injury, infectious disease, malnutrition, and psychiatric disorders due to flooding; malnutrition due to drought; increased pollen concentration leading to increased allergic rhinitis; changes in the geographic patterns of vector-borne diseases; increased indoor allergens and pests due to increased indoor dampness; and reduced indoor air quality due to reduced natural ventilation. Pathways not directly related to ambient air pollution are not discussed further in this paper.

\section{Role of reactive nitrogen in ambient air pollution}

The chemistry of $\mathrm{N}$ in the atmosphere is complex. While molecular nitrogen $\left(\mathrm{N}_{2}\right)$ and nitrous oxide $\left(\mathrm{N}_{2} \mathrm{O}\right)$ are essentially inert in the troposphere, $\mathrm{Nr}$ species (including nitrogen oxides $\left(\mathrm{NO}_{\mathrm{x}}=\mathrm{NO}+\right.$ $\left.\mathrm{NO}_{2}\right)$, nitrate $\left(\mathrm{NO}_{3}{ }^{-}\right)$, ammonia $\left(\mathrm{NH}_{3}\right)$ ammonium $\left(\mathrm{NH}_{4}{ }^{+}\right)$, and organic $\mathrm{N}$-containing species such as peroxyacetyl nitrate $\left(\mathrm{C}_{2} \mathrm{H}_{3} \mathrm{NO}_{5}\right)$, interact with a range of other compounds to form pollutants such as $\mathrm{O}_{3}$, and $\mathrm{PM}$ (e.g., as ammonium nitrate $\left(\mathrm{NH}_{4} \mathrm{NO}_{3}\right)$ ). The responsible chemical reactions and the resulting pollutant concentrations are influenced by meteorology, including precipitation, wind speed, the height of the atmospheric boundary layer and solar radiation. These factors, in conjunction with both natural and anthropogenic emissions, make $\mathrm{N}$ an important consideration in examining interactions of climate change and the $\mathrm{N}$ cycle and its impact on both air quality and human health.

Reactive nitrogen emissions and the nitrogen cycle

Understanding the sources of $\mathrm{N}$ is critical for determining mitigation strategies and for understanding the impact of climate change. Sources of $\mathrm{N}$ oxides to the atmosphere include fossil fuel combustion (e.g., emissions from power plants and mobile sources), biomass burning, agriculture, soils and lightning strikes. The majority of $\mathrm{NO}_{\mathrm{x}}$ emissions come from combustion-related activities. Ammonia is derived primarily from agricultural activities (e.g., emissions from fertilized soils and from livestock wastes) with other anthropogenic activities, such as catalytic converters in cars, contributing smaller amounts.

Interactions between chemistry and meteorology

Reactive $\mathrm{N}$, particularly $\mathrm{NO}_{\mathrm{x}}$, and carbon monoxide (CO), volatile organic compounds (VOCs) and methane $\left(\mathrm{CH}_{4}\right)$, react in the presence of sunlight to form $\mathrm{O}_{3}$, 
a pollutant which adversely impacts environmental and human health. Volatile organic compounds are emitted from both vegetation and anthropogenic sources (e.g., mobile and industrial sources). While anthropogenic VOC emissions dominate in most cities, more than $50 \%$ of VOCs for some areas of the US, such as in the Southeast, are produced by vegetation (SOS, Southern Oxidants Study 2004). The interactions of $\mathrm{NO}_{\mathrm{x}}$ and VOCs in the formation of $\mathrm{O}_{3}$ is non-linear, resulting in areas where the control of one over the other can result in unanticipated consequences depending upon whether the environment is $\mathrm{NO}_{\mathrm{x}}$ or VOC limited (Jacob 1999). As discussed later in this section, the impact of vegetation sources of VOCs on pollution formation is expected to be altered with climate change and $\mathrm{N}$ interactions.

Reactions of $\mathrm{NO}_{\mathrm{x}}$ also contribute to secondary particulates (e.g., $\mathrm{NH}_{4} \mathrm{NO}_{3}$ ) through interactions with $\mathrm{NH}_{3}$, water vapor and other particles. In addition, secondary organic aerosols (SOA) form in the atmosphere when organic gases react with oxidants, including the nitrate radical $\left(\mathrm{NO}_{3}\right)$. Among other sources, the production of SOA also occurs from VOCs, further complicating the N-climate-air pollution system. Thus, the chemical interactions and physical processes involving $\mathrm{N}$ is intrinsically linked with meteorology and environmental conditions (e.g., chemicals present, oxidation state). For example, solar radiation increases photolytic activity generating more $\mathrm{O}_{3}$ during the warmer seasons, and during the warmest hours of the day, yet more PM in the atmosphere causes local scale cooling. Ventilation, caused by higher wind speeds, cleanses the atmosphere, whereas stagnant conditions trap pollutants and their precursors allowing them to react to form photochemical smog and elevated concentrations of $\mathrm{O}_{3}$ and particulates. Precipitation "washes out" particulate $\mathrm{N}$ species, causing these ambient particles to deposit to the landscape or onto water bodies (Jacob 1999). Climate change is expected to alter both long term temperature and precipitation trends (Jacob and Winner 2009), which in turn, will impact N-related processes and air quality.

\section{Nitrogen-associated ambient air pollution and health}

A growing body of evidence demonstrates that $\mathrm{N}$-related air pollutants are hazardous for human health. The evidence linking $\mathrm{NO}_{\mathrm{x}}, \mathrm{O}_{3}$ and the fine size fraction of $\mathrm{PM}\left(\mathrm{PM}_{2.5}\right)$, all currently regulated by the EPA, is summarized in Table 1 (US EPA 2006, 2008, 2009). While the detailed mechanisms are not completely understood and are beyond the scope of this summary, it is thought that pollutants can work through several pathways, including direct pulmonary irritation, suppression of the immune system, disruption of the autonomic nervous system, and through systemic inflammation oxidative stress pathways. For $\mathrm{PM}$, much of the research has focused on $\mathrm{PM}_{2.5}$ because of the ability of the smaller particles to penetrate deeper into the respiratory tract. Despite the growing interest regarding the health impact of the coarse PM size fraction, relatively few studies have examined the coarse size fraction.

In addition, less is known regarding the health effects related specifically to the $\mathrm{NO}_{3}{ }^{-}$component of $\mathrm{PM}_{2.5}$ and SOA's. For other N-related compounds in ambient air, such as $\mathrm{N}_{2} \mathrm{O}$ and gaseous $\mathrm{NH}_{3}$, there is little or no evidence that they cause health effects at current typical ambient concentrations. There is however, evidence that gaseous $\mathrm{NH}_{3}$ can cause health effects at higher concentrations such as those experienced in confined animal feeding operations and other occupational settings (ATSDR 2011). Furthermore, $\mathrm{N}_{2} \mathrm{O}$ indirectly affects human health by leading to stratospheric $\mathrm{O}_{3}$ depletion, which can impact health by increasing UV radiation that is able to reach the Earth's surface.

Susceptible and vulnerable subgroups

There is growing interest in identifying subgroups in the population that are particularly susceptible and/or vulnerable to the health effects of ambient air pollution. Definitions of susceptibility and vulnerability vary, but generally susceptibility refers to populations or characteristics with an increased risk of adverse health effects due to air pollution exposure (e.g., genetics, age, sex, pre-existing disease), while vulnerability often refers to factors that may increase exposure (e.g., proximity to a source, housing characteristics). The terms susceptibility and vulnerability are often used interchangeably. The issues of susceptibility and vulnerability in relation to the health effects of air pollution (specifically for PM) have recently been reviewed (Sacks et al. 2011). Populations considered especially susceptible to the health 
Table 1 Summary of conclusions from previous reviews regarding relationship between nitrogen-related ambient air pollutants and human health

\begin{tabular}{|c|c|c|}
\hline Pollutant/assessment & $\begin{array}{l}\text { Evidence indicates a causal or likely causal } \\
\text { relationship }\end{array}$ & $\begin{array}{l}\text { Evidence is suggestive of a causal relationship } \\
\text { (but is currently insufficient) }\end{array}$ \\
\hline $\begin{array}{l}\mathrm{NO}_{\mathrm{x}} \text { (frequently } \\
\text { measured as } \mathrm{NO}_{2} \text { ) }\end{array}$ & $\begin{array}{l}\text { Short-term exposure and respiratory } \\
\text { morbidity, including: }\end{array}$ & $\begin{array}{l}\text { Short-term exposure and mortality, including respiratory } \\
\text { and cardiovascular mortality }\end{array}$ \\
\hline $\begin{array}{l}2008 \text { EPA Integrated } \\
\text { Science Assessment } \\
\text { (ISA) }\end{array}$ & $\begin{array}{l}\text { Impaired host defense systems } \\
\text { Increased lung inflammation and sensitivity, } \\
\text { particularly among asthmatics } \\
\text { Increased coughing, wheezing, and asthma } \\
\text { symptoms } \\
\text { Decreased lung function } \\
\text { Increased hospital visits }\end{array}$ & $\begin{array}{l}\text { Long-term exposure and respiratory morbidity, } \\
\text { including: } \\
\text { Decreased lung function } \\
\text { Decreased lung growth and function in children }\end{array}$ \\
\hline $\begin{array}{l}\text { Ozone } \\
2006 \text { EPA Air Quality } \\
\text { Criteria Document } \\
\text { (AQCD) }\end{array}$ & $\begin{array}{l}\text { Short-term exposure and respiratory } \\
\text { morbidity, including: } \\
\text { Impaired host defense systems } \\
\text { Increased lung inflammation and sensitivity, } \\
\text { particularly among asthmatics } \\
\text { Increased coughing, wheezing, and asthma } \\
\text { symptoms } \\
\text { Decreased lung function } \\
\text { Increased hospital visits }\end{array}$ & $\begin{array}{l}\text { Short-term exposure and cardiovascular disease } \\
\text { morbidity, including decreased heart function and } \\
\text { increased hospital visits } \\
\text { Short-term exposure and mortality, including respiratory } \\
\text { and cardiovascular mortality }\end{array}$ \\
\hline $\begin{array}{l}\mathrm{PM}_{2.5} \\
2009 \text { EPA ISA for PM }\end{array}$ & $\begin{array}{l}\text { Short-term and long-term exposure and } \\
\text { respiratory and cardiovascular disease } \\
\text { morbidity } \\
\text { Short-term and long-term exposure and } \\
\text { mortality, including respiratory and } \\
\text { cardiovascular mortality }\end{array}$ & $\begin{array}{l}\text { Exposure during pregnancy and early childhood and } \\
\text { adverse reproductive and developmental outcomes } \\
\text { Long-term exposure and cancer }\end{array}$ \\
\hline
\end{tabular}

effects of ambient air pollutants include those with pre-existing respiratory and cardiovascular diseases (e.g., asthma, chronic obstructive pulmonary disease, congestive heart failure), those with underlying hypertension or diabetes, children and older adults, and the developing fetus (Sacks et al. 2011). Recent evidence also suggests that obesity may increase the adverse effects of ambient air pollution (Sacks et al. 2011). Additionally, several genetic polymorphisms involved in oxidative stress and other biologic pathways have been shown to increase susceptibility to the adverse effects of air pollutants, although further research is needed to confirm these findings (Sacks et al. 2011). Low socioeconomic status has also been seen to increase susceptibility; mechanisms likely include pre-existing disease, nutritional status, and reduced or differential access to medical care (Sacks et al. 2011). Geographic proximity to traffic and other pollution sources may also influence vulnerability and susceptibility to adverse health effects. For example, there is growing evidence of the increased risk of health effects due to traffic emissions (Health Effects Institute 2010). Vulnerability to cumulative environmental hazards is greater among specific racial-ethnic and socioeconomic groups (Su et al. 2009). The US Bureau of the Census' American Housing Survey for 2009 estimated that 19,612,000 year-round, occupied housing units (17.5\% of total units) were within 300 feet (92 meters) of a 4-or-more-lane highway, railroad, or airport; and these percentages were higher for African-American households (25\%), Hispanic households (22\%), households below poverty level (22\%), and renter-occupied housing units (26\%) (US Census 2011).

Mortality, morbidity, and economic impacts

The health effects described above and in Table 1 impact a large portion of the US population. A recent analysis (Fann et al. 2011) estimated that 2005 levels of $\mathrm{PM}_{2.5}$ and $\mathrm{O}_{3}$ were responsible for between 130,000 and 320,000 $\mathrm{PM}_{2.5}$-related and 4,700 $\mathrm{O}_{3}$-related 
premature deaths, or about $6.1 \%$ of total deaths from all causes in the continental US (using the lower end of the range for premature deaths). In other words, 1 in 20 deaths in the US were attributable to $\mathrm{PM}_{2.5}$ and $\mathrm{O}_{3}$ exposure. This same analysis attributed almost 200,000 non-fatal heart attacks, 90,000 hospital admissions due to respiratory or cardiovascular illness, 2.5 million cases of aggravated asthma among children, and many other human health impacts from exposure to these two air pollutants. Among populations aged 65-99, the analysis estimated nearly 1.1 million years of potential life lost from $\mathrm{PM}_{2.5}$ exposure and approximately 36,000 potential life years lost from $\mathrm{O}_{3}$ exposure.

Fann et al. (2011) found that the confluence of poor air quality, population size and density, and baseline health status caused the largest number of estimated $\mathrm{PM}_{2.5}$-related premature mortalities to occur within the Northeast, Southeast, and Midwestern US. Among urban areas, the largest estimated impacts occur in Los Angeles, Chicago, Detroit, Pittsburgh, Houston, New York, Philadelphia, and Boston. Among the 10 most populous counties in the US, the percentage of deaths attributable to $\mathrm{PM}_{2.5}$ and $\mathrm{O}_{3}$ range from $3.5 \%$ in San Jose to $10 \%$ in L.A. The analysis demonstrated that, despite significant recent improvements in air quality in recent decades, $\mathrm{PM}_{2.5}$ and $\mathrm{O}_{3}$ continue to present significant risks to public health.

The health impacts of air pollution not only constitute a serious societal threat, they also pose a significant economic burden, through hospital admissions, emergency room visits, and lost work and school days. Conversely, reducing air pollution decreases health impacts (Fann and Risley 2010) and results in substantial economic benefits to American society (Chestnut and Mills 2005). A recent study (US EPA 2011) calculated the costs and benefits of implementing the Clean Air Act Amendments (CAAA) of 1990. The benefits primarily related to reducing human health effects from exposures to fine particles and ground-level $\mathrm{O}_{3}$. This study found that the economic value of these improvements is estimated to reach almost $\$ 2$ trillion $\left(\mathrm{USD}_{2006}\right)$ for the year 2020 , a value that vastly exceeds the cost of efforts to comply with the requirements of the 1990 CAAA. Moreover, the study also conducted economy-wide modeling to estimate the effect of the 1990 Amendments on overall US economic growth and the economic welfare of American households. When some of the beneficial economic effects of clean air programs were incorporated along with the costs of these programs, economywide modeling projected net overall improvements in economic growth and welfare. These improvements are projected to occur because cleaner air leads to better health and productivity for American workers as well as savings on medical expenses for air pollutionrelated health problems.

\section{Interaction of nitrogen and climate change-impact on air quality}

As discussed previously, meteorology and $\mathrm{Nr}$ both play important roles in ambient air pollution formation. In order to hypothesize about the likely impact of climate change (i.e., changing meteorological patterns) on ambient air pollution, the complex interactions between meteorology and $\mathrm{Nr}$ need to be considered (Fig. 1).

Climate impact on emissions

Climate change is expected to impact both anthropogenic and natural emissions of $\mathrm{Nr}$ and VOCs. The extent, and even direction, of the impact on anthropogenic $\mathrm{NO}_{\mathrm{x}}$ emissions is not certain. For example, higher temperatures are expected to increase the use of air conditioners, while also decreasing the need for heating, both of which would impact electricity demand and generation. Further, $\mathrm{NO}_{\mathrm{x}}$ emissions are generally subject to increasingly stringent controls aimed at reducing $\mathrm{O}_{3}$ levels to meet the National Ambient Air Quality Standards (NAAQS). Thus, the net impact on total anthropogenic $\mathrm{NO}_{\mathrm{x}}$ emissions is not known (Grambsch 2002). However, climateinduced anthropogenic $\mathrm{NO}_{\mathrm{x}}$ emission increases (for example, from increased use of air conditioning) would likely occur during the summer, when extreme $\mathrm{O}_{3}$ events are most common and when $\mathrm{O}_{3}$ formation is most sensitive to $\mathrm{NO}_{\mathrm{x}}$ emissions (e.g., Jacob 1999; Liao et al. 2010; Weaver et al. 2009).

In terms of natural sources of ambient $\mathrm{N}$ concentrations, studies suggest that incidences of lightning will increase, leading to more $\mathrm{NO}_{\mathrm{x}}$ formation, although the impact on pollutant concentrations at ground level is expected to be small (Henderson et al. 2011; Weaver et al. 2009; Kaynak et al. 2008). Climate change may also impact soil $\mathrm{NO}_{\mathrm{x}}$ emissions 
and soil and manure $\mathrm{NH}_{3}$ emissions, although the size of this impact is not clear. Higher temperatures generally lead to increased emissions from soils and from manure, but the supply of $\mathrm{Nr}$ is also a prime determinant (see Robertson et al. agriculture paper in this issue for further discussion) (e.g., Pinder et al. 2008; Wu et al. 2008). Volatile organic carbon emissions from vegetation are expected to respond to climate change, but they are also linked to $\mathrm{N}$ availability, which affects leaf-level physiology involved in VOC production (e.g., Heald et al. 2008, 2009; Lamarque et al. 2005; Wu et al. 2012).

Wildland fires, both prescribed and spontaneous, can also be impacted by climate and N. Fires emit particulate matter, $\mathrm{NO}_{\mathrm{x}}$, and VOCs, leading to increased PM (primary and secondary) and $\mathrm{O}_{3}$. There is also evidence suggesting that fires lead to increased sulfate $\left(\mathrm{SO}_{4}^{-2}\right)$ formation in the plumes (e.g., Buzcu et al. 2006), which can in addition be components of PM. Studies suggest that there will be an increased frequency and severity of fires due to higher temperatures, decreased soil moisture, and extended drought periods (Easterling et al. 2007; Kinney 2008; Westerling et al. 2006). Nitrogen enrichment could also lead to invasion of fire-prone exotic grasses, further increasing fire risk and emissions (see Porter et al. paper on biodiversity in this issue) (Rao et al. 2010). Emissions from wildfires in North America can have important consequences for air quality both regionally and at sites thousands of kilometers from the fire (Spracklen et al. 2009; Wotawa and Trainer 2000). Wildfires are a significant direct source of atmospheric pollutants such as $\mathrm{CO}, \mathrm{NO}_{\mathrm{x}}$, VOCs and PM. These pollutants are precursors for $\mathrm{O}_{3}$ production and as a result, wildfires may also lead to increases in $\mathrm{O}_{3}$ concentrations (Wotawa and Trainer 2000; Pfister et al. 2008).

Climate impacts on atmospheric pollutant processing

Global climate change is expected to impact both the physical and chemical processing of pollutants in the atmosphere. Higher temperatures will tend to increase the rate of photochemical processing, leading to the faster generation of secondary products, including $\mathrm{O}_{3}$, which is sensitive to temperature increases. One of the more dramatic impacts that climate change is expected to have on air pollutant concentrations is through the potential for increased periods of stagnation during the summer, leading to decreased dispersion of $\mathrm{O}_{3}$ and $\mathrm{O}_{3}$ precursors. This, alone, is expected to lead to increased levels of $\mathrm{O}_{3}$ and other secondary species. Most models predict an increased number of days exceeding current regulatory $\mathrm{O}_{3}$ standards (Kinney 2008; Bell et al. 2007). In addition, this is expected to be more prevalent in certain urban areas already experiencing high $\mathrm{O}_{3}$, particularly in the Eastern US. Further, these periods of higher temperature would increase vegetation VOC emissions. Combined, the increased stagnation and VOC emissions are estimated to increase $\mathrm{O}_{3}$ levels in the more highly impacted US regions by $2-8 \mathrm{ppb}$, (Weaver et al. 2009; Mickley et al. 2004). Studies suggest that this will make $\mathrm{O}_{3}$ formation in those areas even more sensitive to $\mathrm{NO}_{\mathrm{x}}$ emissions (Liao et al. 2010).

Furthermore, global warming is expected to extend the $\mathrm{O}_{3}$ season as higher temperatures increase chemical processing rates and vegetation VOC emissions increase earlier in spring, and continue later in autumn (Nolte et al. 2008). To a degree, this is muted because photolysis rates in early spring and late autumn are not as high as during the middle summer months.

The role of climate change on high wintertime $\mathrm{O}_{3}$ episodes is less clear. Evidence from a recent study by Schnell et al. (2009) observed elevated diurnal levels of $\mathrm{O}_{3}$ in Wyoming during the winter when high pressure conditions prevailed (e.g., low wind speeds, low clouds, and cold temperatures). It was suggested that these meteorological conditions produced a shallow temperature inversion that trapped high concentrations of $\mathrm{O}_{3}$ precursors (e.g., $\mathrm{NO}_{x}$ from nearby oil and gas wells) in the lower atmosphere overnight, which were then photolyzed during the next day under high light conditions (including reflection of $\mathrm{UV}$ by the snow cover) to produce higher day-time $\mathrm{O}_{3}$ concentrations (Schnell et al. 2009).

The impact of climate change on $\mathrm{PM}_{2.5}$ levels is less clear than for $\mathrm{O}_{3}$. Along with more severe stagnation episodes in some regions, climate change is expected to alter precipitation patterns. While more severe stagnation events can lead to increased pollutant levels, areas where rainfall is expected to increase and/or become more extended (in part due to increased cloudiness), secondary pollutant formation is expected to decrease. Rain will further reduce levels by removing PM and soluble gases. Higher temperatures will also shift the thermodynamic equilibrium away from nitric acid combining with $\mathrm{NH}_{3}$ to form $\mathrm{NH}_{4} \mathrm{NO}_{3}$ aerosol, leading to lower levels of that 
aerosol product (Stelson and Seinfeld 1982; Dawson et al. 2007; Mahmud et al. 2010). Thus, the impact that climate change will have on $\mathrm{PM}_{2.5}$, will likely vary, with the potential for some areas to experience increases, and others decreases. Although some recent research suggests that the net impact will be an overall increase in $\mathrm{PM}_{2.5}$ (Tagaris et al. 2007), this remains an area of active research. Increased drought would lead to increases in soil-dust PM, though ground cover changes associated with the N-cycle and climate modification of groundcover would likewise play a role.

Climate change is also expected to increase atmospheric water vapor concentrations. Water vapor reacts with the excited oxygen radical (O1D) derived from $\mathrm{O}_{3}$ photolysis to form hydroxyl radicals $(\mathrm{OH})$, increasing the rate of chemical destruction of organics and $\mathrm{NO}_{2}$ (e.g., reducing $\mathrm{CH}_{4}$ ). In radical-limited areas (e.g., areas high in $\mathrm{NO}_{\mathrm{x}}$ ), this will lead to more rapid formation of secondary pollutants like $\mathrm{O}_{3}$. In radicalrich $\left(\mathrm{NO}_{\mathrm{x}}\right.$-limited $)$ regions, this reaction sequence can lead to reducing $\mathrm{O}_{3}$ as less $\mathrm{O} 1 \mathrm{D}$ is available to, ultimately, re-form $\mathrm{O}_{3}$.

While emissions of $\mathrm{Nr}$ are expected to decline in North America and Europe, emissions in South and East Asia are expected to first increase and then decline more slowly (HTAP 2010). Despite this potential increase in the sources of pollution for intercontinental transport of $\mathrm{Nr}$ and its products, warmer oceanic temperatures are expected to increase water vapor over the ocean, resulting in a reduction in cross-hemispheric $\mathrm{O}_{3}$ transport from South and East Asia through increases in $\mathrm{O}_{3}$ loss rates over remote oceanic regions (Jacob and Winner 2009).

\section{Interaction of nitrogen and climate change-impact on human health}

As demonstrated in previous sections, $\mathrm{Nr}$ and climate change have independent impacts on human health by way of ambient air pollution; $\mathrm{N}$ and climate change likely also interact in several ways to impact human health (Fig. 1). As described in the previous section, while factors associated with climate change would likely lead to a net increase in ambient air pollution, these predictions are often calculated in the absence of any net change in $\mathrm{Nr}$ emissions, which is highly unlikely. The changing $\mathrm{N}$ cycle along with global climate change will likely result in additional impacts on human health due to ambient air pollution through several mechanisms, including shifting patterns and timing of air pollution exposure and the interaction of increased temperature and air pollution. Furthermore, the changes in $\mathrm{Nr}$ and climate will occur in the context of changing susceptibility and vulnerability in the population. Table 2 summarizes examples of likely scenarios through which climate change and $\mathrm{Nr}$ could interact to impact ambient air pollution and subsequent human health effects.

Health impacts of shifts in pollution exposure

A shift towards higher pollutant distributions with increasing temperatures will also increase the proportion of the population exposed to higher pollution levels. For example, a longer $\mathrm{O}_{3}$ season could result in $\mathrm{O}_{3}$ exposure overlapping the spring and fall respiratory viral and asthma seasons, which are known to have increased activity during these periods. While the impact of this overlap is not clear, there is evidence that $\mathrm{O}_{3}$ and other pollutants can enhance the susceptibility to and the severity of, respiratory infections and increase sensitization to allergens (Chauhan and Johnston 2003; Ciencewicki and Jaspers 2007; Rusznak et al. 1996).

Health impacts of increased exposure to fire emissions

As previously noted, it is also likely that climate change and increased $\mathrm{N}$ deposition will both result in increased frequency and exposure to wildfire emissions, which can be an important source of $\mathrm{N}$-ambient air pollution. Wildfires produce severe local plumes of $\mathrm{PM}$, oxides of $\mathrm{N}$ and other air pollutants with resulting human exposures, especially among firefighters (Adetona et al. 2011; Neitzel et al. 2009; Reisen 2006). Exposures to wildfire smoke have been associated with increased emergency department visits, especially among individuals with pre-existing cardiopulmonary conditions such as congestive heart failure (Rappold et al. 2011; Mirabelli et al. 2009; Hänninen et al. 2009; Delfino et al. 2003). These observational studies have recently been supported by reports of increased inflammatory markers in healthy volunteers in controlled clinical exposures to wood smoke (Ghio et al. 2011). The general adverse health effects of exposures to woodsmoke were the subject of a review by Naeher et al. (2007). 
Table 2 Examples of the impact of nitrogen and climate change interactions on air quality and human health

\begin{tabular}{|c|c|c|c|c|}
\hline Process & Impact on air quality & Impact on human exposure & $\begin{array}{l}\text { Net impact on } \\
\text { human health } \\
\text { (-adverse; } \\
\text { +beneficial) }\end{array}$ & $\begin{array}{l}\text { Confidence } \\
\text { (1 higher, } 3 \\
\text { lowest) }\end{array}$ \\
\hline $\begin{array}{l}\text { Increased summertime } \\
\text { stagnation events }\end{array}$ & $\begin{array}{l}\text { Increased } \mathrm{O}_{3} \text { (the "climate } \\
\text { penalty") and increased } \\
\text { sensitivity of } \mathrm{O}_{3} \text { to } \mathrm{NO}_{\mathrm{x}} \\
\text { emissions }\end{array}$ & Increased $\mathrm{O}_{3}$ exposure & - & 1 \\
\hline $\begin{array}{l}\text { Increased vegetative growth } \\
\text { due to increased } \mathrm{CO}_{2} \text { and } \mathrm{Nr}\end{array}$ & $\begin{array}{l}\text { Increased biogenic VOC } \\
\text { emissions; potentially } \\
\text { increased wild-land fire } \\
\text { emissions }\end{array}$ & $\begin{array}{l}\text { Increased } \mathrm{O}_{3} \text { and } \mathrm{PM} \\
\quad \text { (including } \mathrm{SOA} \text { ) exposure }\end{array}$ & - & 1 \\
\hline $\begin{array}{l}\text { Increased wild-land fires due to } \\
\text { drought and increased } \\
\text { temperature }\end{array}$ & $\begin{array}{l}\text { Increased biogenic VOC, PM } \\
\text { and } \mathrm{NO}_{\mathrm{x}} \text { emissions }\end{array}$ & $\begin{array}{l}\text { Increased } \mathrm{NO}_{\mathrm{x}}, \mathrm{O}_{3} \text { and } \mathrm{PM} \\
\text { exposure }\end{array}$ & - & 1 \\
\hline Increased absolute humidity & $\begin{array}{l}\text { Increased } \mathrm{OH} \text {, decreased long } \\
\text { range } \mathrm{O}_{3} \text { transport, increased } \\
\text { rate of sulfate and nitrate } \\
\text { formation }\end{array}$ & $\begin{array}{l}\text { Small decrease in } \mathrm{O}_{3} \text { transport; } \\
\text { could lead to increased local } \\
\mathrm{O}_{3} \text { formation and exposure }\end{array}$ & \pm & 3 \\
\hline Increased temperature & $\begin{array}{l}\text { Decreased or increased } \\
\text { ammonium nitrate formation } \\
\text { depending on region }\end{array}$ & $\begin{array}{l}\text { Decreased or increased PM } \\
\text { exposure }\end{array}$ & \pm & 3 \\
\hline $\begin{array}{l}\text { Longer } \mathrm{O}_{3} \text { season due to higher } \\
\text { temperatures }\end{array}$ & $\begin{array}{l}\text { Increased } \mathrm{O}_{3} \text { levels earlier in } \\
\text { season }\end{array}$ & $\begin{array}{l}\text { Extended } \mathrm{O}_{3} \text { exposure, } \\
\text { potentially to a period when } \\
\text { respiratory diseases are more } \\
\text { prevalent. }\end{array}$ & - & 3 \\
\hline $\begin{array}{l}\text { Simultaneous increase extreme } \\
\mathrm{O}_{3} \text { and high temperature } \\
\text { events }\end{array}$ & NA & $\begin{array}{l}\text { Increased exposure to } \\
\text { simultaneous high } \mathrm{O}_{3} \text { and } \\
\text { temperatures, particularly for } \\
\text { populations without access to } \\
\text { central air conditioning. }\end{array}$ & - & 3 \\
\hline $\begin{array}{l}\text { Changing precipitation patterns } \\
\text { with increased precipitation } \\
\text { in some regions, decreased in } \\
\text { others (leading to drought) }\end{array}$ & $\begin{array}{l}\text { Precipitation scavenges } \\
\text { pollutants (PM and precursor } \\
\text { gases), and cloudiness } \\
\text { reduces pollutant formation. } \\
\text { Drought can increase } \\
\text { pollutants (including soil } \\
\text { dust) }\end{array}$ & Decreased PM exposure & + & 3 \\
\hline
\end{tabular}

Health impacts of increased exposure to allergens

Increased $\mathrm{N}$ deposition and climate change factors are also likely to impact aeroallergen patterns. Allergic diseases are an increasing source of morbidity in the US and other developed countries. Nearly 5 million Americans have asthma and more than 50 million Americans suffer from allergic disease; both conditions are exacerbated by pollen and mold and both have been increasing over the past few decades (Kinney 2008). Increased $\mathrm{N}$ deposition has been shown to increase pollen production (Townsend et al. 2003). Climate change, including warmer temperatures and changing precipitation patterns, can lead to longer pollen seasons and increased seasonal pollen production (Kinney 2008; Shea et al. 2008). Furthermore, carbon dioxide $\left(\mathrm{CO}_{2}\right)$ another greenhouse gas has been shown to stimulate pollen production and potency (Kinney 2008; Shea et al. 2008).

Health impacts from the interaction of heat waves and pollutant exposure

While the independent effects of the N-related ambient air pollutants and temperature extremes (e.g., heat waves, night time temperature, and other temperature 
extremes; McGeehin and Mirabelli 2001; O'Neill and Ebi 2009; Peng et al. 2011) are well-documented, the joint effects of reduced air quality and temperature have received less attention. Meteorological conditions that produce heat waves are generally high pressure systems with stagnant wind conditions that are accompanied by increased levels of many air pollutants. This natural covariation of heat waves and air pollution limits the ability of observational studies to estimate their joint health effects (McMichael et al. 2001; Thurston and Ito 2001). Recent studies have provided evidence that the health effects of ambient air pollutants, including $\mathrm{O}_{3}$ and $\mathrm{PM}$, are enhanced when temperatures are higher, particularly in regions with typically cooler temperatures (Ren et al. 2009; Li et al. 2011; Dear et al. 2005).

Health impacts on changing populations of susceptible and vulnerable groups

It is important to recognize that the health impacts predicted to result from changing $\mathrm{N}$ emissions and deposition and global climate change will occur in the context of changing population susceptibility and vulnerability. Susceptibility to the joint impacts of air pollutants and global climate change will depend on the same factors that confer susceptibility to the independent effects of air pollutants and heat stress. Aging populations, increasing prevalence of respiratory and cardiovascular disease, and increasing prevalence of obesity and type II diabetes will all enhance the health effects described previously. These factors are no longer just concerns of developed countries. Cardiovascular disease, obesity, and type II diabetes are increasingly important in low- and middle-income countries as well; cardiovascular disease is now the leading the cause of death worldwide and the second leading cause of death in low-income countries (Narayan et al. 2010; Reddy 2004; Yusuf et al. 2001, 2004).

Vulnerability to the joint impacts of air pollutants and global climate change will reflect the non-uniform distribution of human exposures (Morello-Frosch et al. 2011). Climate change is predicted to impact food availability, flooding, and drought, all of which may result in population movement to urban areas. This population movement may lead to increased proximity to traffic and other sources of air pollution. Vulnerability to the impact of both air pollution and temperature is also greater in the absence of air conditioning. Air conditioning is known to prevent or reduce infiltration of many ambient air pollutants indoors. Individuals without air conditioning will have much greater vulnerability to aeroallergens (Delfino et al. 1997) and to heat stress (IOM 2011; Ostro et al. 2010; Richard et al. 2011). In a recent study, vulnerability to heat waves was largely determined by socioeconomic status, including education, poverty and race; social isolation; air conditioning prevalence; and general health condition, including advanced age and diabetes (Reid et al. 2009). Adaptation to climate change may also increase the factors that confer increased susceptibility to the adverse effects of air pollution, especially obesity. A recent study has linked accessibility of urban parks as protective for childhood obesity (Wolch et al. 2010). Avoidance of outdoor exercise in response to prolonged heat events will therefore tend to increase obesity and thus susceptibility to ambient air pollutants. The accessibility of urban public recreation resources also raises issues of disparities and environmental justice (Dahmann et al. 2010). Additionally, disparities in access to air conditioned facilities may also be much greater under these conditions.

\section{Implications for policy}

The major routes where climate change and $\mathrm{Nr}$ will likely interact to modify pollutant concentrations and have implications for policy and management, particularly implementation of the Clean Air Act (CAA) have been identified. The CAA is the primary federal tool for controlling air pollution in the US. Last amended in 1990, the CAA requires EPA to set NAAQS for widespread pollutants from numerous and diverse sources considered harmful to public health and the environment (Bachmann 2007). The CAA established two types of NAAQS. Primary standards set limits to protect public health, including the health of potentially susceptible populations such as asthmatics, children, and the elderly. Secondary standards set limits to protect public welfare, including protection against visibility impairment, damage to animals, crops, vegetation, and buildings. The CAA requires periodic review of both the science upon which the standards are based and the standards themselves.

The NAAQS provide policy drivers for controlling six "criteria" air pollutants and the precursor 
atmospheric emissions that lead to their formation. In relation to the health effects described above, the most relevant health-based, or primary standards are those for $\mathrm{PM}_{2.5}$ and $\mathrm{O}_{3}$. For $\mathrm{PM}_{2.5}$, there are two health-based standards. The current annual standard is $15 \mu \mathrm{g} / \mathrm{m}^{3}$, meaning that, to attain this standard, the 3-year average of the weighted annual mean $\mathrm{PM}_{2.5}$ concentrations from single or multiple community-oriented monitors must not exceed $15.0 \mu \mathrm{g} / \mathrm{m}^{3}$. ${ }^{1}$ The $24-\mathrm{h} \mathrm{PM}_{2.5}$ standard is $35 \mu \mathrm{g} / \mathrm{m}^{3}$, requiring that the 3 -year average of the 98th percentile of 24-h concentrations at each population-oriented monitor within an area must not exceed $35 \mu \mathrm{g} / \mathrm{m}^{3}$. For $\mathrm{O}_{3}$, the primary standard is $0.075 \mathrm{ppm}$, which requires that the 3-year average of the fourthhighest daily maximum 8-h average $\mathrm{O}_{3}$ concentrations, measured at each monitor within an area over each year, must not exceed $0.075 \mathrm{ppm}$.

Due to the overall decreasing trend in $\mathrm{NO}_{\mathrm{x}}$ and sulfur dioxide $\left(\mathrm{SO}_{2}\right)$ emissions, related air pollution has changed, with substantial improvements seen in $\mathrm{O}_{3}$ and fine particle concentrations in many regions (US EPA 2010). Nationally, ground-level $\mathrm{O}_{3}$ concentrations were $10 \%$ lower in 2008 than in 2001, and the trend showed a notable decline after 2002. In the Eastern US, 2006-2008 air monitoring data showed that $\mathrm{O}_{3}$ air quality improved in almost all of the 104 areas designated to be in nonattainment for the 1997 8-h NAAQS. Nationally, annual and 24-h $\mathrm{PM}_{2.5}$ concentrations declined by 17 and $19 \%$, respectively, between 2001 and 2008. Despite this substantial progress, many air pollution issues remain. For example, even though $\mathrm{O}_{3}$ concentrations in 2008 were among the lowest since 2002, many areas still measured concentrations above the 2008 NAAQS for $\mathrm{O}_{3}$. Similarly, some areas remain in non-attainment with the NAAQS for $\mathrm{PM}_{2.5}$. In 2008, more sites exceeded the level of the 24-h $\mathrm{PM}_{2.5}$ standard than the annual $\mathrm{PM}_{2.5}$ standard. Eighteen sites exceeded the annual standard and 55 sites exceeded the 24-h standard, while 14 sites exceeded both.

As described above, air quality has been improving and is expected to improve further as $\mathrm{NO}_{\mathrm{x}}$ emissions decrease due to control programs currently in placehowever, even with these future emission reductions in place, air pollution may worsen due to the "climate

\footnotetext{
${ }^{1}$ The US EPA recently proposed to strengthen the annual standard NAAQS for $\mathrm{PM}_{2.5}$ to $12-13 \mu \mathrm{g} / \mathrm{m}^{3}$. See http://www. epa.gov/airquality/particlepollution/actions.html.
}

penalty". In other words, the same amount of NOx reduction may result in less $\mathrm{O}_{3}$ mitigation in a warmer world-hence the term "climate penalty" (Wu et al. 2008).

There is a substantial and growing body of literature showing that climate change has the potential to impact the extent, severity, timing, length and geography of $\mathrm{O}_{3}$ pollution and high $\mathrm{O}_{3}$ episodesinfluencing health and economic burdens across large parts of the country in the future (Racherla and Adams 2009; Mickley et al. 2004; Mickley 2007; Hogrefe et al. 2004; Jacob and Winner 2009). The "climate penalty" has important policy implications. For example, even while changes in US emissions will continue to be critical for attaining $\mathrm{O}_{3}$ air quality standards, climate change by itself may significantly worsen the severity and frequency of high $\mathrm{O}_{3}$ events in the US (Racherla and Adams 2009). Thus, higher $\mathrm{O}_{3}$ levels due to future climate change alone could erode the gains made through future US $\mathrm{NO}_{\mathrm{x}}$ emission reductions, meaning that stronger emission controls may be needed to meet a given air quality standard. In addition, policy makers must plan appropriately for background $\mathrm{O}_{3}$ increases due to projected increases in non-US anthropogenic emissions that, as described above, may also erode the progress made in decreasing pollutant emissions from domestic sources. And, finally, the end result will be continued serious impacts to human health and concomitant economic burdens.

In contrast to the "climate penalty", there is some evidence that some areas will see increased cloud cover and precipitation, generally leading to overall reductions in pollutants, particularly $\mathrm{O}_{3}$ and secondary PM constituents (Tagaris et al. 2007), and that climaterelated changes could result in reduced air pollution. These aspects of climate change could be a possible countervailing phenomenon leading to better air quality, impacting both human health and the ability of states to attain the NAAQS for $\mathrm{O}_{3}$ and fine PM. Other mechanisms will play more minor roles, and may increase or decrease pollutant levels; further research is needed in this area.

Another important health-related policy issue at the $\mathrm{N}$-climate nexus involves the potential for changing frequency, intensity, and spatial extent and distribution of fire. The elevated concentrations of air pollution due to wildfire may impact the ability of areas to attain and maintain the NAAQS for pollutants 
associated with wildfires. In many areas of the country, prescribed fire is an important management tool employed by federal and state land management agencies, often as a means to lower the fuel load in order to lessen the extent and severity of wildfire. To the extent that climate change and $\mathrm{N}$ loading influence, either separately or jointly, natural or managed fire in the US, with accompanying impacts on air quality, this will likely have implications for land management and the functioning and budgets of agencies responsible for overseeing federal and state lands.

\section{Summary and key research needs}

Global climate change and $\mathrm{Nr}$ in the environment will interact through several mechanisms to impact ambient air pollution and may have subsequent adverse effects on human health. Given the complex interactions, changes in local and regional meteorology patterns due to global climate change and changes in the $\mathrm{N}$ cycle must be examined concurrently when discussing any likely future impacts on human health (e.g., the "climate penalty"). Among the most important climate change- $\mathrm{N}$ interactions in terms of ambient air pollution and human health effects, include the increased number of "high" $\mathrm{O}_{3}$ days, the increased length of the $\mathrm{O}_{3}$ season, increased vegetative VOC emissions from plant activity, and increased VOCs, $\mathrm{PM}$ and $\mathrm{NO}_{\mathrm{x}}$ from fires.

The state of knowledge regarding the likely impact of the interaction of $\mathrm{N}$ and climate change on ambient air quality and human health contains some critical gaps. The interaction between climate change and changes in $\mathrm{Nr}$ in the environment will likely lead to changes in the levels of vegetation VOC emissions, and potentially the composition of those emissions as well. Oxidation of VOC leads to secondary organic aerosols, however, the potential health implications of SOA's are not known. A better understanding of the health effects of SOA's should be a focus of further study, not only to address the question of the combined impacts of climate and the $\mathrm{N}$ cycle, but to better understand the current impact of vegetation emissions on health.

Additionally, $\mathrm{NH}_{3}$ emissions result primarily from agricultural practices, including the use of fertilizers and large confined livestock operations. Whereas the majority of $\mathrm{NO}_{\mathrm{x}}$ emissions fall under air quality regulations, $\mathrm{NH}_{3}$ emissions from agriculture are mostly unregulated. In contrast to recent decreases in $\mathrm{NO}_{\mathrm{x}}$ emissions, which are expected to continue due to air quality regulations, $\mathrm{NH}_{3}$ emissions are expected to increase. The potential contribution of $\mathrm{NH}_{3}$ emissions to fine particle formation is an issue of concern. An area for further work involves the impact of $\mathrm{NH}_{3}$ emissions on our ability to attain fine particulate standards for human health, including the combined effects of $\mathrm{NH}_{3}$ emissions and climate change on air quality and human health.

One of the areas where climate change and the $\mathrm{N}$ cycle may have an effect on health is on the change in pollen emissions. However, we need improved understanding of the combined and interactive effects of climate change and $\mathrm{N}$ cycling in the environment on production rates and types of pollen.

Finally, given the relative lack of research in the area, further work is needed to evaluate the interaction of ambient air pollution and temperature (specifically high temperature and heat waves) on human health. Additionally, more research is needed to evaluate potential susceptibility and vulnerability factors, particularly those that are predicted to increase (e.g., obesity, underlying disease, older age, nutritional deficits, proximity to sources) at the same time that population experiences the impacts of global climate change.

Acknowledgments We thank several reviewers whose comments improved the quality of this manuscript. This work resulted from a workshop supported by NSF Research Coordination Network awards DEB-0443439 and DEB1049744 and by the David and Lucille Packard Foundation. Disclaimers: The material in this document has been subject to U.S. Environmental Protection Agency (EPA) technical and policy review, and approved for publication. The views expressed by individual authors; however, are their own and do not necessarily reflect those of EPA. Mention of trade names, products, or services does not convey, and should not be interpreted as conveying, official U.S. Environmental Protection Agency(EPA) approval, endorsement, or recommendation.

Open Access This article is distributed under the terms of the Creative Commons Attribution License which permits any use, distribution, and reproduction in any medium, provided the original author(s) and the source are credited.

\section{References}

Adetona O, Dunn K, Hall DB, Achtemeier G, Stock A, Naeher LP (2011) Personal PM(2.5) exposure among wildland firefighters working at prescribed forest burns in Southeastern United States. J Occup Environ Hyg 8(8):503-511 
Agency for Toxic Substances and Disease Registry (ATSDR) (2011) ToxFAQs for ammonia. http://www.atsdr.cdc.gov/ toxfaqs/tf.asp?id=10\&tid=12. Accessed November 21, 2011

Bachmann J (2007) Will the circle be unbroken: a history of the US national ambient air quality standards. J Air Waste Manag Assoc 57(6):652-697

Bell ML, Goldberg R, Hogrefe C, Kinney PL, Knowlton K, Lynn B, Rosenthal J, Rosenzweig C, Patz JA (2007) Climate change, ambient ozone, and health in 50 US cities. Clim Change 82(1-2):61-76

Buzcu B, Yue ZW, Fraser MP, Nopmongcol U, Allen DT (2006) Secondary particle formation and evidence of heterogeneous chemistry during a wood smoke episode in Texas. J Geophys Res Atmos 111(D10). doi:10.1029/2005JD00 6143

Chauhan AJ, Johnston SL (2003) Air pollution and infection in respiratory illness. Br Med Bull 68:95-112

Chestnut LG, Mills DM (2005) A fresh look at the benefits and costs of the US Acid Rain Program. J Environ Manage 77(3):252-266

Ciencewicki J, Jaspers I (2007) Air pollution and respiratory viral infection. Inhalation Toxicol 19(14):1135-1146

Confalonieri U, Menne B, Akhtar R, Ebi KL, Hauengue M, Kovats RS, Revich B, Woodward A (2007) Human health. In: Parry ML, Canziani OF, Palutikof JP, van der Linden P, Hanson CE (eds) Climate Change 2007: impacts, adaptation and vulnerability. Contribution of working group ii to the fourth assessment report of the intergovernmental panel on climate change. Cambridge University Press, Cambridge, UK, pp 391-431

Dahmann N, Wolch J, Joassart-Marcelli P, Reynolds K, Jerrett M (2010) The active city? Disparities in provision of urban public recreation resources. Health Place 16(3):431-445

Dawson JP, Adams PJ, Pandis SN (2007) Sensitivity of PM2.5 to climate in the Eastern US: a modeling case study. Atmos Chem Phys 7(16):4295-4309

Dear K, Ranmuthugala G, Kjellström T, Skinner C, Hanigan I (2005) Effects of temperature and ozone on daily mortality during the august 2003 heat wave in France. Arch Environ Occup Health 60:205-212

Delfino RJ, Zeiger RS, Seltzer JM, Street DH, Matteucci RM, Anderson PR, Koutrakis P (1997) The effect of outdoor fungal spore concentrations on daily asthma severity. Environ Health Perspect 105(6):622-635

Delfino RJ, Brummel S, Wu J, Stern H, Ostro B, Lipsett M, Winer A, Street DH, Zhang L, Tjoa T, Gillen DL (2003) The relationship of respiratory and cardiovascular hospital admissions to the southern California wildfires of. Occup Environ Med 66(3):189-197

Easterling WE, Aggarwal PK, Batima P (2007) Food, fibre, and forest products. In: Parry ML, Canziani OF, Palutikof JP, van der Linden PJ, Hanson CE (eds) Climate change 2007: impacts, adaptation and vulnerability. Contribution of working group II to the fourth assessment report of the intergovernmental panel on climate change. Cambridge University Press, Cambridge, UK

Fann N, Risley D (2010) The public health context for PM2.5 and ozone air quality trends. Air quality. Atmos Health. doi:10.1007/s11869-11010-10125-11860
Fann N, Roman HA, Fulcher CM, Gentile MA, Hubbell BJ, Wesson K, Levy JI (2011) Maximizing health benefits and minimizing inequality: incorporating local-scale data in the design and evaluation of air quality policies. Risk Anal 31(6):908-922

Ghio AJ, Soukup JM, Case M, Dailey LA, Richards J, Berntsen J, Devlin RB, Stone S, Rappold A (2011) Exposure to wood smoke particles produces inflammation in healthy volunteers. Occup Environ Med 69(3):170-175

Grambsch A (2002) Climate change and air quality. The potential impacts of climate change on transportation. DOT Center for Climate Change and Environmental Forecasting, USA

Haines A, Patz JA (2004) Health effects of climate change. J Am Med Assoc 291:99-103

Hänninen OO, Salonen RO, Koistinen K, Lanki T, Barregard L, Jantunen M (2009) Population exposure to fine particles and estimated excess mortality in Finland from an East European wildfire episode. J Eposure Sci Environ Epidemiol 19(4):414-422

Heald CL, Henze DK, Horowitz LW, Feddema J, Lamarque JF, Guenther A, Hess PG, Vitt F, Seinfeld JH, Goldstein AH, Fung I (2008) Predicted change in global secondary organic aerosol concentrations in response to future climate, emissions, and land use change. J Geophys Res 113(D5): D05211

Heald CL, Wilkinson MJ, Monson RK, Alo CA, Wang G, Guenther A (2009) Response of isoprene emission to ambient $\mathrm{CO} 2$ changes and implications for global budgets. Glob Change Biol 15(5):1127-1140

Health Effects Institute (2010) Traffic-related air pollution: a critical review of the literature on emissions, exposure, and health effects. In: HEI panel on the health effects of trafficrelated air pollution, Boston, MA

Hemispheric Transport of Air Pollution (HTAP) Task Force Economic Commission for Europe (2010) Hemispheric transport of air pollution 2010 part d: answers to policyrelevant science questions, air pollution studies no. 20. United Nations, New York and Geneva

Henderson BH, Pinder RW, Crooks J, Cohen RC, Hutzell WT, Sarwar G, Goliff WS, Stockwell WR, Fahr A, Mathur R, Carlton AG, Vizuete W (2011) Evaluation of simulated photochemical partitioning of oxidized nitrogen in the upper troposphere. Atmos Chem Phys 11(1):275-291

Hogrefe C, Lynn B, Civerolo K, Ku JY, Rosenthal J, Rosenzweig C, Goldberg R, Gaffin S, Knowlton K, Kinney PL (2004) Simulating changes in regional air pollution over the eastern United States due to changes in global and regional climate and emissions. J Geophys Res Atmos 109(D22). doi:10.1029/2004JD004690

Houghton JT, Ding Y, Griggs DJ, Noguer M, van der LInden PJ, D. Xiaosu D (2001) Climate change 2001: the scientific basis. Cambridge University Press, Cambridge, UK

Institute of Medicine (IOM) (2011) Climate change, the indoor environment, and health. The National Academies Press, Washington, DC

Jacob DJ (1999) Introduction to atmospheric chemistry. Princeton University Press, Princeton

Jacob DJ, Winner DA (2009) Effect of climate change on air quality. Atmos Environ 43(1):51-63 
Kaynak B, Hu Y, Martin RV, Russell AG, Choi Y, Wang Y (2008) The effect of lightning $\mathrm{NO}_{\mathrm{x}}$ production on surface ozone in the continental United States. Atmos Chem Phys 8(17):5151-5159

Kinney PL (2008) Climate change, air quality, and human health. Am J Prev Med 35(5):459-467

Lamarque J-F, Kiehl JT, Brasseur GP, Butler T, Cameron-Smith P, Collins WD, Collins WJ, Granier C, Hauglustaine D, Hess PG, Holland EA, Horowitz L, Lawrence MG, McKenna D, Merilees D, Prather MJ, Rasch PJ, Rotman D, Shindell D, Thornton P (2005) Assessing future nitrogen deposition and carbon cycle feedback using a multimodel approach: analysis of nitrogen deposition. J Geophys Res 110:D19303. doi:19310.11029/12005JD005825

Li GX, Zhou MG, Cai Y, Zhang YJ, Pan XC (2011) Does temperature enhance acute mortality effects of ambient particle pollution in Tianjin City, China. Sci Total Environ 409(10):1811-1817

Liao KJ, Tagaris E, Russell AG, Amar P, He S, Manomaiphiboon K, Woo JH (2010) Cost analysis of impacts of climate change on regional air quality. J Air Waste Manag Assoc 60(2):195-203

Mahmud A, Hixson M, Hu J, Zhao Z, Chen SH, Kleeman MJ (2010) Climate impact on airborne particulate matter concentrations in California using seven year analysis periods. Atmos Chem Phys 10(22):11097-11114

McGeehin MA, Mirabelli M (2001) The potential impacts of climate variability and change on temperature-related morbidity and mortality in the United States. Environ Health Perspect 109:185-189

McMichael M, Githeko A, Akhtar R (2001) Human health in climate change 2001: impacts, adaptation, and vulnerability. In: McCarthy JJ, Canziani OF, Leary NA, Dokken DJ, White KS (eds) Climate change: impacts, adaptation, and vulnerability: contribution of working group II to the intergovernmental panel on climate changes. Cambridge University Press, Cambridge, pp 451-485

Mickley LJ (2007) A future short of breath? Possible effects of climate change on smog. Environment 49(6):34-43

Mickley LJ, Jacob DJ, Field BD, Rind D (2004) Effects of future climate change on regional air pollution episodes in the United States. Geophys Res Lett 31(24):L24103

Mirabelli MC, Kunzli N, Avol E, Gilliland FD, Gauderman WJ, McConnell R, Peters JM (2009) Respiratory symptoms following wildfire smoke exposure airway size as a susceptibility factor. Epidemiology 20(3):451-459

Morello-Frosch R, Zuk M, Jerrett M, Shamasunder B, Kyle AD (2011) Understanding the cumulative impacts of inequalities in environmental health: implications for policy. Health Aff 30(5):879-887

Naeher LP, Brauer M, Lipsett M, Zelikoff JT, Simpson CD, Koenig JQ, Smith KR (2007) Woodsmoke health effects: a review. Inhalation Toxicol 19(1):67-106

Narayan KMV, Ali MK, Koplan JP (2010) Global health global noncommunicable diseases - where worlds meet. N Engl J Med 363(13):1196-1198

Neitzel R, Naeher LP, Paulsen M, Dunn K, Stock A, Simpson CD (2009) Biological monitoring of smoke exposure among wildland firefighters: a pilot study comparing urinary methoxyphenols with personal exposures to carbon monoxide, particular matter, and levoglucosan. J Eposure Sci Environ Epidemiol 19(4):349-358

Nolte CG, Gilliland AB, Hogrefe C, Mickley LJ (2008) Linking global to regional models to assess future climate impacts on surface ozone levels in the United States. J Geophys Res 113(D14):D14307

O’Neill MS, Ebi KL (2009) Temperature extremes and health: impacts of climate variability and change in the United States. J Occup Environ Med 51(1):13-25

Ostro B, Rauch S, Green R, Malig B, Basu R (2010) The effects of temperature and use of air conditioning on hospitalizations. Am J Epidemiol 172(9):1053-1061

Peng RD, Bobb JF, Tebaldi C, McDaniel L, Bell ML, Dominici F (2011) Toward a quantitative estimate of future heat wave mortality under global climate change. Environ Health Perspect 119(5):701-706

Pfister GG, Wiedinmyer C, Emmons LK (2008) Impacts of the fall 2007 California wildfires on surface ozone: Integrating local observations with global model simulations. Geophys Res Lett 35(19). doi:10.1029/2007GL031972

Pinder RW, Gilliland AB, Dennis RL (2008) Environmental impact of atmospheric NH3 emissions under present and future conditions in the eastern United States. Geophys Res Lett 35:L12808. doi:12810.11029/12008GL033732

Racherla PN, Adams PJ (2009) US ozone air quality under changing climate and anthropogenic emissions. Environ Sci Technol 43(3):571-577

Rao LE, Allen EB, Meixner T (2010) Risk-based determination of critical nitrogen deposition loads for fire spread in southern California deserts. Ecol Appl 20(5):1320-1335

Rappold AG, Stone SL, Cascio WE, Neas LM, Kilaru VJ, Carraway MS, Szykman JJ, Ising A, Cleve WE, Meredith JT, Vaughan-Batten H, Deyneka L, Devlin RB (2011) Peat bog wildfire smoke exposure in rural North Carolina is associated with cardiopulmonary emergency department visits assessed through syndromic surveillance. Environ Health Perspect 119(10):1415-1420

Reddy KS (2004) Cardiovascular disease in non-Western countries. N Engl J Med 350(24):2438-2440

Reid CE, O'Neill MS, Gronlund CJ, Brines SJ, Brown DG, Diez-Roux AV, Schwartz J (2009) Mapping community determinants of heat vulnerability. Environ Health Perspect 117(11):1730-1736

Reisen F (2006) Brown SK (2009) Australian firefighters' exposure to air toxics during bushfire burns of autumn 2005 and. Environ Int 35(2):342-352

Ren C, Williams GM, Mengersen K, Morawska L, Tong S (2009) Temperature enhanced effects of ozone on cardiovascular mortality in 95 large US Communities, 1987-2000: assessment using the NMMAPS data. Arch Environ Occup Health 64:177-184

Richard L, Kosatsky T, Renouf A (2011) Correlates of hot day air-conditioning use among middle-aged and older adults with chronic heart and lung diseases: the role of health beliefs and cues to action. Health Educ Res 26(1):77-88

Rusznak C, Devalia JL, Davies RJ (1996) Airway response of asthmatic subjects to inhaled allergen after exposure to pollutants. Thorax 51(11):1105-1108

Sacks JD, Stanek LW, Luben TJ, Johns DO, Buckley BJ, Brown JS, Ross M (2011) Particulate matter-induced health 
effects: who is susceptible? Environ Health Perspect 119(4):446-454

Schnell RC, Oltmans SJ, Neely RR, Endres MS, Molenar JV, White AB (2009) Rapid photochemical production of ozone at high concentrations in a rural site during winter. Nat Geosci 2(2):120-122

Shea KM, Truckner RT, Weber RW, Peden DB (2008) Climate change and allergic disease. J Allergy Clin Immunol 122(3):443-453

Southern Oxidants Study (SOS) (2004) In: Cowling EB, Furiness C (eds) The state of the southern oxidant study (SOS) policy relevant findings in ozone and PM2.5 pollution research 1995-2003. NC State University, Raleigh

Spracklen DV, Mickley LJ, Logan JA, Hudman RC, Yevich R, Flannigan MD, Westerling AL (2009) Impacts of climate change from 2000 to 2050 on wildfire activity and carbonaceous aerosol concentrations in the western United States. J Geophys Res 114(D20):D20301

Stelson AW, Seinfeld JH (1982) Relative-humidity and temperature-dependence of the ammonium-nitrate dissociation-constant. Atmos Environ 16(5):983-992

Su JG, Morello-Frosch R, Jesdale BM, Kyle AD, Shamasunder B, Jerrett M (2009) An index for assessing demographic inequalities in cumulative environmental hazards with application to Los Angeles, California. Environ Sci Technol 43(20):7626-7634

Tagaris E, Manomaiphiboon K, Liao KJ, Leung LR, Woo JH, He S, Amar P, Russell AG (2007) Impacts of global climate change and emissions on regional ozone and fine particulate matter concentrations over the United States. J Geophys Res Atmos 112(D14):D14312

Thurston GD, Ito K (2001) Epidemiological studies of acute ozone exposures and mortality. J Expo Anal Environ Epidemiol 11(4):286-294

Townsend AR, Howarth RW, Bazzaz FA, Booth MS, Cleveland CC, Collinge SK, Dobson AP, Epstein PR, Keeney DR, Mallin MA, Rogers CA, Wayne P, Wolfe AH (2003) Human health effects of a changing global nitrogen cycle. Front Ecol Environ 1(5):240-246

U.S. Census (2009) American housing survey 2009. http:// www.census.gov/hhes/www/housing/ahs/ahs09/ahs09.html. Accessed, July 2011

US-EPA (U.S. Environmental Protection Agency) (2006) Air quality criteria for ozone and related photochemical oxidants. U.S. Environmental Protection Agency EPA, 600/R05/004aF-cF, Washington, DC

US-EPA (U.S. Environmental Protection Agency) (2008) Integrated science assessment (ISA) for oxides of nitrogen and sulfur-ecological criteria (final report) (ISA). EPA/600/ R-08/082. Office of Research and Development, National Center for Environmental Assessment, Research Triangle Park, NC
US-EPA (U.S. Environmental Protection Agency) (2009) Integrated science assessment for particulate matter (final report). EPA-600-R-08-139F. National Center for Environmental Assessment-RTP Division. December. http:// cfpub.epa.gov/ncea/cfm/recordisplay.cfm?deid=216546

US-EPA (U.S. Environmental Protection Agency) (2010) Our nation's air: status and trends through 2008. Office of Air Quality Planning and Standards, Research Triangle Park, NC

US-EPA (U.S. Environmental Protection Agency) (2011) The benefits and costs of the clean air act from 1990 to 2020. US EPA, Washington, DC

Weaver CP, Liang XZ, Zhu J, Adams PJ, Amar P, Avise J, Caughey M, Chen J, Cohen RC, Cooter E, Dawson JP, Gilliam R, Gilliland A, Goldstein AH, Grambsch A, Grano D, Guenther A, Gustafson WI, Harley RA, He S, Hemming B, Hogrefe C, Huang HC, Hunt SW, Jacob DJ, Kinney PL, Kunkel K, Lamarque JF, Lamb B, Larkin NK, Leung LR, Liao KJ, Lin JT, Lynn BH, Manomaiphiboon K, Mass C, McKenzie D, Mickley LJ, O’Neill SM, Nolte C, Pandis SN, Racherla PN, Rosenzweig C, Russell AG, Salathe E, Steiner AL, Tagaris E, Tao Z, Tonse S, Wiedinmyer C, Williams A, Winner DA, Woo JH, Wu S, Wuebbles DJ (2009) A preliminary synthesis of modeled climate change impacts on US regional ozone concentrations. Bull Am Meteorol Soc 90(12):1843-1863

Westerling AL, Hidalgo HG, Cayan DR, Swetnam TW (2006) Warming and earlier spring increase western US forest wildfire activity. Science 313(5789):940-943

Wolch J, Jerrett M, Reynolds K, McConnell R, Chang R, Dahmann N, Brady K, Gilliland F, Su JG, Berhane K (2010) Childhood obesity and proximity to urban parks and recreational resources: a longitudinal cohort study. Health Place 16(3):137-157

Wotawa G, Trainer M (2000) The influence of Canadian forest fires on pollutant concentrations in the United States. Science 288(5464):324-328

Wu S, Mickley LJ, Leibensperger EM, Jacob DJ, Rind D, Streets DG (2008) Effects of 2000-2050 global change on ozone air quality in the United States. J Geophys Res 113(D6):D06302

Wu S, Mickley LJ, Kaplan JO, Jacob DJ (2012) Impacts of changes in land use and land cover on atmospheric chemistry and air quality over the 21 st century. Atmos Chem Phys 12:1597-1609

Yusuf S, Reddy S, Ounpuu S, Anand S (2001) Global burden of cardiovascular diseases-part I: general considerations, the epidemiologic transition, risk factors, and impact of urbanization. Circulation 104(22):2746-2753

Yusuf S, Vaz M, Pais P (2004) Tackling the challenge of cardiovascular disease burden in developing countries. Am Heart J 148(1):1-4 